\title{
The Perspective of Corruption Risk Management Strategy in Indonesia
}

\author{
Arman Sahri Harahap*, Husain Syam, Haedar Akib, Akbar Mukmin, Hasnawi Haris \\ Department of Public Administration \\ Universitas Negeri Makassar \\ Makassar, Indonesia \\ *armansrhar@gmail.com
}

\begin{abstract}
State problems have placed corruption as the enemy that most threatens the stability of the country. This can be seen from various countries experiencing the brink of destruction due to corruption by state officials. In fact, this official is expected to be a fortress capable of realizing the vision and mission of a country. Therefore, a strategy to deal with the risk of corruption is needed, especially in Indonesia, which is a developing country. The approach used is qualitative research in looking at the strategies carried out by government holders in the period 2004 to 2019. Data collection techniques use interview techniques and documentation. Data analysis uses interactive models developed by experts, namely: 1) Data Collection, 2) Data Display, 3) Data Condensation, 4) Conclusion: Drawing / Verifying (Miles, Huberman, Saldana, 2014). The results showed that the handling of the risk of corruption of the two government holders, namely the VI and VII Presidents, had increased. Moreover, the Government of the Seventh President experienced a significant increase. However, at the end of 2019 there was a decline in performance because the law underwent a very drastic change. The impact of these changes resulted in public distrust of the government, both legislative and executive, as an extension of the community's hands in the context of realizing a just and prosperous society as stated in the 1945 constitution of the Republic of Indonesia.
\end{abstract} KPK

Keywords—corruption risk, corruption, corruption eradication,

\section{INTRODUCTION}

Corruption is a problem in Indonesia and even internationally [1-3]. Various corruption eradication policies designed by the government have been designed and implemented. However, the corruption eradication policy does not automatically become an effective instrument. Indonesia's Corruption Perception Index in 2019 is still at number 85 out of 180 countries with a score of 40 out of a total score of 100 [4]. Indonesia's Corruption Perception Index, which did not experience a significant increase, even tended to be stagnant, namely 36 (2015), and 37 (2016, 2017, and 2018) [5]. Data from the Corruption Eradication Commission of the Republic of Indonesia (KPK RI) shows that the private sector and echelon I / II / III officials have the highest ranking for corruption perpetrators from 2004 to 2017. In addition, the Anti-Corruption Behaviour Index (IPAK) published by the Central Statistics Agency To measure the level of public permissiveness towards corrupt behaviour, it shows that the public's understanding and assessment tends to be more idealistic in anti-corruption, but that society in practice when dealing with public services is still corrupt $[6,7]$.

Repressive handling of corruption by law enforcement officials can be seen as successful [2]. However, the risk of corruption and the incidence of corruption did not decrease. In terms of the quality of corruption, it can be said that corruption is increasingly massive, systematic, structured and decentralized. At least 36 regional heads were arrested through hand-catching operations. This shows that organizational leaders who should be role models or strategies for employees and society are actually the perpetrators or at least allow corruption to occur. The form of neglect included low commitment to strengthening the Government Internal Control System (SPIP) and increasing the capability of the Government Internal Supervisory Apparatus (abbreviated as APIP). Conducting members of the organization as well as ignoring or ignoring acts of corruption that occur are important factors in the normalization of such corruption. This omission forms a routine which can then become a "culture" that is getting stronger when the actors do the rationalization and rationalization and then get support from the leaders and colleagues.

Among other things, opportunities for corruption are manifested in the form of protracted postponement measures. Public service officers have repeatedly delayed or stalled for reasons that cannot be accounted for so that there is no certainty in the provision of public services [8-10]. Organizational leaders have a great opportunity to commit corruption by abusing their authority. In addition to many occurring in the process of procuring goods / services and licensing services, this also occurs in the human resource management process of state civil servants [11-14]. These various forms of rationalization and socialization tactics of corruption have resulted in corruption continuing and being institutionalized in a seemingly harmless process $[15,16]$. 
A series of policies and actions to eradicate corruption were also carried out during the New Order era, including issuing Presidential Decree (Kepres) No.28 of 1967 concerning the Establishment of a Corruption Eradication Team, Law No.3 of 1971 concerning Corruption Crimes, and Presidential Instruction No. 91977 concerning Control Operations and Law No. $11 / 1980$ on the Crime of Bribery. By considering the current conditions, Indonesia can be seen as having a complete anti-corruption instrument, namely the existence of anticorruption laws and regulations, the establishment of a KPK institution and the existence of a corruption court. In addition, there is also the Long Term 2012-2025 National Strategy for the Prevention and Eradication of Corruption (Stranas PPK) which is the basis for the government to make efforts to eradicate corruption.

Presidential Instruction Number 10 of 2016 concerning Action to Prevent and Eradicate Corruption in 2016 and 2017 outlines strategies for preventing corruption and strategies for law enforcement that are realized through actions of public institutions at the central and regional levels. In the Presidential Instruction, action plans related to the management of crosssectoral development programs include: 1) Optimizing the implementation of licensing and investment policies, 2) Reforming land and spatial governance, 3) Increasing transparency and accountability of procurement of goods and services, and 4) Governance of state-owned and private enterprises. Following the Presidential Instruction, a Joint Decree from the Chairman of the Corruption Eradication Commission, the Minister for National Development Planning / Head of the National Development Planning Agency, the Minister of Home Affairs, the Minister for Administrative Reform and Bureaucratic Reform, and the Presidential Chief of Staff on Corruption Prevention Action for 2019-2020 as guidelines for the implementation of the 2019-2020 Corruption Prevention Action by Ministries, Agencies, Local Governments and other stakeholders.

Based on the implementation of these regulations, it turns out that the eradication of corruption is ineffective, and the need for increased supervision of cross-sectoral development programs, researchers consider it important to develop a risk management strategy. The strategy needs to comprehensively cover the anti-corruption system and culture of the organization. In addition, given the characteristics of development programs that are cross-sectoral in nature, the corruption risk management model should also include aspects of relations and coordination with various institutions related to the management of corruption risk.

\section{MethodS}

This research uses normative research methods [17]. In the approach used to review relevant references to the strategies adopted by the Indonesian government in dealing with the risk of corruption, this article examines the various policies undertaken by each country's leader, namely during President VI (Susilo Bambang Yodoyono) and President VII (Joko Widodo). describes the data and facts that occur in handling the risk of corruption from the two leaders of these countries. The data collection technique uses secondary data obtained from online news information presented through television media and online newspapers such as Kompas, Warta Indonesia and other media that are considered relevant.

\section{RESULTS AND DISCUSSION}

Eradicating corruption in Indonesia provides fresh air for society. This is because law enforcers, namely the Corruption Eradication Commission (KPK) have carried out their duties properly. The effort being made is to enforce a transparent government, so officials are needed to be free from corruption. During the period the Government of Susilo Bambang Yudoyono (SBY) has shown an increase in corruption risk handling. Although seen from the level of the number of cases is still low. However, during the Joko Widodo administration, the performance of corruption eradication in general has increased when viewed from the cases handled by the KPK. Compared to the previous administration period, statistical data based on the 2019 KPK Annual Report shows an increase from year to year. However, the amendment to the KPK Law correlates with the number of cases that drastically decreased in 2019. The trend of Corruption Crime cases in 2004-2019 can be seen in Figure 1.

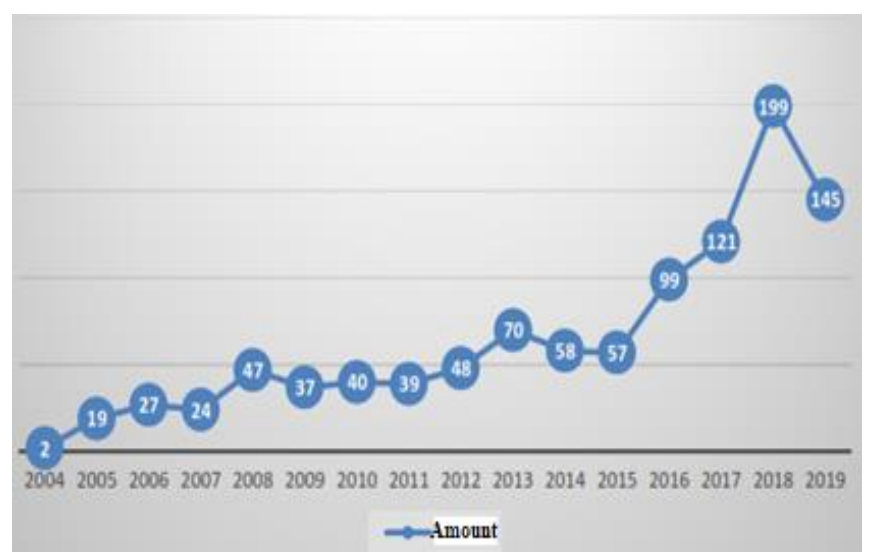

Fig. 1. Corruption crime 2004-2019.

Figure 1 shows the trend of corruption eradication performance carried out by the KPK increased sharply during the administration of President Joko Widodo, to be precise starting in 2016 which increased by 42 cases compared to the previous year. The increase in cases continued to be experienced until 2018 until it reached 199 cases. However, this trend has decreased to 145 cases in 2019 which can be attributed to the revision of the Corruption Eradication Commission Law which significantly reduces some of the agency's responsibilities. In more detail, trends in corruption cases by mode and perpetrator are presented in Figure 2. 


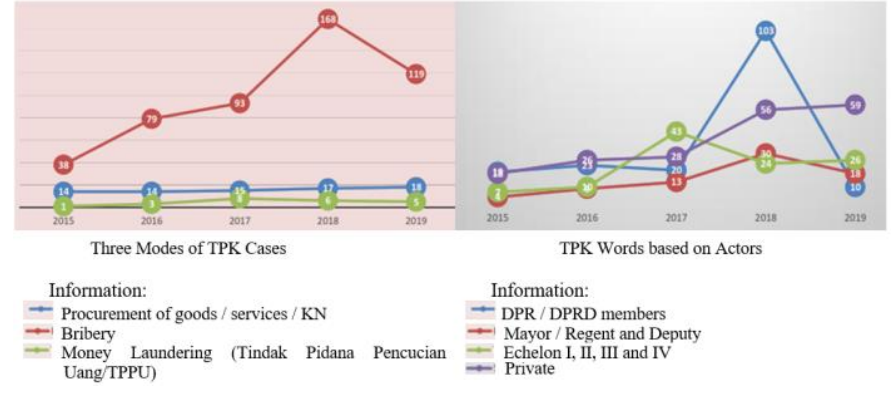

Fig. 2. Corruption Crime Case (abbreviated as TPK) by Mode and Perpetrators of 2015-2019.

Efforts to strengthen the eradication of corruption in the era of President Joko Widodo were marked by the signing of Presidential Instruction Number 10 of 2016 concerning Actions to Prevent and Eradicate Corruption. The Minister for National Development Planning / Head of the National Development Planning Agency Bambang Brodjonegoro at that time emphasized that ministries, agencies, and local governments were obliged to implement the Inpres. The Presidential Instruction for 2016 and 2017 focuses on two things, namely the matter of corruption prevention and law enforcement in the field of eradicating corruption. The two focuses are implemented in seven sectors, namely the extractive / mining industry, infrastructure, the private sector, state revenue, trade administration, BUMN and the procurement of goods and services. The Presidential Instruction aims to improve the corruption perception index, improve ease of doing business, and government transparency.

In addition, the Presidential Decree No. 54/2018 concerning the National Strategy for Prevention of Corruption. In these two policies, the President wants to strengthen the position and role of the Corruption Eradication Commission (KPK). This super-body institution must be backed up so that it is able to deal with corruptors. The government also issued Government Regulation number 43 of 2018 concerning procedures for implementing community participation and giving awards in the prevention and eradication of criminal acts of corruption. With PP 43/2018, people who provide information to law enforcers regarding suspected corruption will receive awards in the form of certificates and premiums with a maximum amount of IDR 200 million.

The efforts to strengthen the KPK taken by President Jokowi through Presidential Regulations (Perpres), Presidential Instruction (Inpres) and government regulations issued during his reign are unfortunately weakened by the revision of the KPK Law and the provision of reduced sentences for convicts in corruption cases. This is the basis for assessing the government's low commitment to efforts to eradicate corruption. The incomplete Novel Baswedan case and the decision to release Syarif Arsyad Temenggung, a former corruption defendant, has also drawn criticism from the Bank Indonesia Liquidity Assistance Payment Certificate (abbreviated as SKL BLBI). Indonesia Corruption Watch
(ICW) also noted that the average conviction of corruption perpetrators was only 2 years and 5 months in prison. From 2004 to 2019, the KPK handled a total of 1,032 cases, with $683(66.18 \%)$ being bribery. In 2019 the mode of bribery remained the most common, amounting to $82.07 \%$ (119 cases out of a total of 145 cases).

The problem of bribery is a problem that has existed in society for a very long time. In general, bribes are given to influential people or officials in order to do or not do something related to their position. People who give bribes usually give bribes so that their wishes are achieved, either in the form of certain benefits or to be free from a punishment or legal process. So, it is not surprising that the ones who are bribed the most are officials in the government bureaucracy who have an important role in deciding something, for example in granting permits or granting government projects. Bribes are often given to law enforcers, for example police, prosecutors, judges. Likewise, for customs officials, taxes and officials related to the granting of permits in the form of business permits, building permits and others. In the Natural Resources sector, bribery occurs in almost every line of administration-planning to control. For example, in the forestry sector, bribes per permit per year reached 688 million22 billion per year.

Looking at the reality of handling the risk of corruption that occurs in Indonesia has provided a good image for the government in actualizing the regulations that have been set. However, at the end of 2019 it experienced a very sharp decline. This was due to the heating up political conditions which resulted in drastic changes in the regulations regarding the handling of corruption [18-20]. As a result, many Indonesians feel disappointed with this regulation, which results in the KPK feeling that it no longer has independence in guarding corruption crimes. This is in accordance with the opinion of experts who reveal that the role of law in dealing with corruption greatly determines transparency in a government [21,22]. In addition, the role of the president is very helpful in the successful handling of corruption risks. However, the public experienced disappointment with the government, both the legislature and the executive, which had made and approved laws that were very detrimental to the community. Although it is ideal that if in a country the level of corruption is low, the country will be successful in dealing with corruption [23-25].

\section{CONCLUSION}

Dealing with the risk of corruption in Indonesia is very important, because of how many irregularities have occurred both at the central and regional levels. Therefore, in the era of Susilo Bambang Yudoyono (SBY) administration, efforts have been made to deal with the risk of corruption. This can be seen from the legislation that has been made which is entrusted by the Corruption Eradication Commission (KPK) as an extension of the state's hand to eradicate corruption. This trust that was given to the KPK was felt during the administration 
of President Joko Widodo in answering the state's problems in handling corruption crimes which are increasingly significant in guarding officials in combating corruption in Indonesia. However, in 2019 it experienced a decline due to changes in legislation which were considered to have weakened the KPK's duties and functions in eradicating corruption.

In order to anticipate corruption in Indonesia, it is hoped that from all circles, both at the executive and legislative and judicial levels, jointly enforce existing regulations and revise laws that can weaken the duties, main and function of the KPK as the front guard in eradicating corruption.

\section{ACKNOWLEDGMENT}

Our thanks go to the conference manager who is willing to publish this article. In addition, we also express our gratitude to Makassar State University for providing access to participate in activities and in guarding this article so that it can be published.

\section{REFERENCES}

[1] S.O. Sihombing, "Youth perceptions toward corruption and integrity: Indonesian context," Kasetsart J. Soc. Sci., vol. 39, no. 2, pp. 299-304, 2018.

[2] S. Isra, Y. Yuliandri, F. Amsari and H. Tegnan, "Obstruction of justice in the effort to eradicate corruption in Indonesia," Int. J. Law, Crime Justice, vol. 51, pp. 72-83, 2017.

[3] C. Joseph, J. Gunawan, Y. Sawani, M. Rahmat, J. Avelind Noyem and F. Darus, "A comparative study of anti-corruption practice disclosure among Malaysian and Indonesian Corporate Social Responsibility (CSR) best practice companies," J. Clean. Prod., vol. 112, pp. 28962906, 2016

[4] A. Alfada, "The destructive effect of corruption on economic growth in Indonesia: A threshold model," Heliyon, vol. 5, no. 10, pp. e02649, 2019.

[5] A. Sabani, M.H. Farah and D.R. Sari Dewi, "Indonesia in the Spotlight: Combating Corruption through ICT enabled Governance," Procedia Comput. Sci., vol. 161, pp. 324-332, 2019.

[6] E.K. Owusu, A.P.C. Chan and M.R. Hosseini, "Impacts of anticorruption barriers on the efficacy of anti-corruption measures in infrastructure projects: Implications for sustainable development," J. Clean. Prod., vol. 246, pp. 119078, 2020.

[7] J. Xie and Y. Zhang, "Anti-corruption, government intervention, and corporate cash holdings: Evidence from China," Econ. Syst., vol. 44, no. 1, pp. $100745,2020$.

[8] A. Barr, M. Lindelow and P. Serneels, "Corruption in public service delivery: An experimental analysis,” J. Econ. Behav. Organ., vol. 72, no. 1, pp. 225-239, 2009.

[9] N.P. Antonakas, I. Seimenis and N. Konstantopoulos, "The Organizational Structure of the Public Service and its Role on the Level of Corruption: The Case of Greek Tax Administration," Procedia - Soc. Behav. Sci., vol. 148, pp. 494-500, 2014.

[10] J. Davis, "Corruption in Public Service Delivery: Experience from South Asia's Water and Sanitation Sector," World Dev., vol. 32, no. 1, pp. 5371, 2004.

[11] R. Budi, H. Akib, Jasruddin and G.D. Dirawan, "Public information management services in South Sulawesi," Int. J. Appl. Bus. Econ. Res., vol. 13 , no. $4,2015$.

[12] H. Akib, Rifdan and M. Guntur, "Quality improvement strategies of academic services and student affairs at the Graduate Program State University of Makassar, Indonesia,” Int. J. Appl. Bus. Econ. Res., vol. 13, no. 4, 2015.

[13] Z.A. Rengifurwarin, H. Akib, Jasruddin and R. Salam, "Snapshot of public service quality in the center for integrated business service (CIBS), cooperative micro small and medium enterprises (CMSME), Maluku province, Indonesia,” J. Entrep. Educ., vol. 21, no. 3, 2018.

[14] D. Daraba, M. Guntur, F. Kartini, dan R. Salam, "The Impact of Village Expansion Policy on Public Service Aspects at Sadar Village Bone-Bone District of North Luwu Regency," in Colloquium, pp. 50, 2018.

[15] Z. Abdul-Baki, A.B. Uthman and A.S. Kasum, "The role of accounting and accountants in the oil subsidy corruption scandal in Nigeria," Crit. Perspect. Account., pp. 102128, 2019.

[16] H. Widodo, H.S.R. Tinambunan, F. Mamunto and H. Haris, Indonesia's Governance System after Amandment of the 1945 Constitution: The Dialectic between Text and Context, 2018.

[17] R. Hardin, "Normative Methodology," Oxford Handb. Polit. Methodol., pp. 1-14, 2008.

[18] J. Sheng, W. Zhou and S. Zhang, "The role of the intensity of environmental regulation and corruption in the employment of manufacturing enterprises: Evidence from China," J. Clean. Prod., vol. 219, pp. 244-257, 2019.

[19] O. Dincer and B. Gunalp, "The effects of federal regulations on corruption in U.S. States," Eur. J. Polit. Econ., vol. 65, pp. 101924, 2020.

[20] H. Chen, Y. Hao, J. Li and X. Song, "The impact of environmental regulation, shadow economy, and corruption on environmental quality: Theory and empirical evidence from China," J. Clean. Prod., vol. 195, pp. 200-214, 2018.

[21] L. Xing and G. Levitin, "Balancing theft and corruption threats by data partition in cloud system with independent server protection," Reliab. Eng. Syst. Saf., vol. 167, pp. 248-254, 2017.

[22] J. Gutmann, F. Padovano and S. Voigt, "Perception vs. experience: Explaining differences in corruption measures using microdata," Eur. J. Polit. Econ., vol. 65, pp. 101925, 2020.

[23] J. Arayankalam, A. Khan and S. Krishnan, "How to deal with corruption? Examining the roles of e-government maturity, government administrative effectiveness, and virtual social networks diffusion," Int. J. Inf. Manage., pp. 102203, 2020.

[24] Q. Liu, T. Luo and G. Tian, "Political connections with corrupt government bureaucrats and corporate M\&A decisions: A natural experiment from the anti-corruption cases in China," Pacific-Basin Financ. J., vol. 37, pp. 52-80, 2016.

[25] S. Choudhury, "WTO membership and corruption," Eur. J. Polit. Econ., vol. 60 , pp. 101806, 2019. 